\title{
Apokalyptik, fortælling og normativitet
}

De to første artikler i dette nummer af Dansk Teologisk Tidsskrift handler om apokalyptikkens særlige form for litteratur. De to sidste om henholdsvis Kainfortællingens udvikling og gudsbegrebets normativitet hos C.S. Peirce.

Johannes' Åbenbaring er for de fleste det mest uhåndterlige skrift i Det Nye Testamente. Geert Hallbäck forsøger med udgangspunkt i kap. 13 på en gang at få mening i galskaben og samtidig med egne ord bevare galskaben i meningen. Hallbäck vil to ting: dels argumentere for en stærk tidshistorisk tolkning, dels foreslå en mulig aktualisering. Hallbäck læser Åbenbaringen som politisk undergrundslitteratur, der tematiserer den næsten tvangsmæssige konflikt mellem politik og tro og derfor åbner den mod nutidige aktualiseringer i situationer, hvor staten positionerer sig som religionskonkurrent.

Det litterære perspektiv på apokalyptikken er omdrejningspunktet for artiklen "Fra apokalyptik til science fiction". Med udgangpunkt i Jakob Ballings sammenligning af Dante's Den guddommelige komedie og Miltons Paradise Lost udvider Søren Jensen perspektivet og inddrager også Abrahams apokalypse (1. årh) og C.S. Lewis' Out of the Silent Planet (1938) i diskussionen om forholdet mellem teologi og fiktion. Søren Jensen finder i kristendommens inkarnationstanke en særlig frigørelse til brug af billedsprog og fiktion, der samtidig udgør den grænse, bag hvilken man ikke kan komme.

Lizette Harritsø undersøger i sin artikel "Kainfortællingen i antikke oversættelser og fortolkninger". Fremfor den sædvanlige modstilling mellem Kain og Abel fokuserer hun på Jahves oversete rolle i fortællingen. I den masoretiske version er Jahves tvetydighed langt mere fremtrædende end den typologiske modstilling af Kain og Abel. Den finder man derimod i Septuagintas græske og Vulgatas latinske oversættelser. Inddragelsen af De Gammeltestamentlige Pseudepigrafer peger på en afgørende prægning herfra på såvel oversættelse som tolkningstradition.

I "Det oversete argument" undersøger Martin Ravn C.S. Peirces vanskeligt forståelige skrift The Neglected Argument for the Reality of God. Martin Ravn vil undersøge relevansen af den teologiske position, som lader sig finde i Peirces essay knyttet til hans forsvar for "the Humble Argument": at en grublen over Gud før eller senere vil medføre tro på hans realitet, og hvor tro samtidigt ikke skal forstås som noget rent intellektuelt, men som en måde at forme sin handlemåde på. Til slut bruger Martin Ravn Peirces forståelse af gudsbegrebet immanente normativitet som korrektiv til den metodologiske naturalisme. 